scientific and technical representatives of the three territories, together with a panel (also nominated by them) of persons specially qualified in particular branches of science and technical matters. This new Committee will be advisory to a new and smaller Board comprising representatives of the High Commission and the three territories, which will be under the chairmanship of the Administrator to the High Commission. The new Board's duties will be, principally, the maintenance of full liaison between the organization and the Governments, determination, with the consent and backing of Governments, of priorities, etc., affecting research, and the review of progress in research. It is expected that the new Board will be constituted shortly. The laboratories operating under the old Industrial Research Board have, during the past few years, carried out research into a large number of matters concerning industrial development in East Africa, in addition to analytical work. These matters include investigations on phosphatic fertilizer production; refractories and ceramics, including bricks and roofing tiles and drain pipes as well as domestic pottery ; cement production; charcoal production with by-products; soda production from Lake Nakuru; and the extraction and treatment of fresh pyrethrum flowers.

Statistics at the Australian National University, Canberra : Prof. P. A. P. Moran

A CHAIR of statistics has recently been created in the Research School of Social Sciences in the Australian National University, Canberra, and Dr. P. A. P. Moran has been elected as its first occupant. Dr. Moran, who is thirty-four, was born in Sydney and educated at St. Stanislaus' College, Bathurst, at the University of Sydney, and at St. John's College, Cambridge. During the Second World War, he served as an experimental officer in the Ministry of Supply and (later) as Australian scientific liaison officer for physics and operational research. Since the War, he has been lecturer in mathematics at Trinity College, Oxford, University lecturer in mathematics, and a senior member of the Oxford Institute of Statistics. $\mathrm{He}$ is a Fellow of the Royal Statistical Society and has played a prominent part in the post-war development of the Society's Research Section, and in the creation of a school of mathematical statistics in Oxford. Apart from earlier work on the pure mathematics of measure, Dr. Moran is chiefly known for his papers on the statistical theory of ranking, and on the theory of stationary time-series. He has collaborated with Prof. A. S. C. Ross on the dating of manuscripts by the statistical analysis of philological data, and with the Oxford Bureau of Animal Population on some problems of population dynamics. At the present he is interested in the problems of estimation arising out of the theory of stochastic processes.

\section{American Scientific Mission to West Germany}

As American scientific mission, headed by Dr. Harold Vagtborg, president of the Southwest Research Institute, San Antonio, Texas, is undertaking a survey of West Germany's scientific research resources under the sponsorship of the Economic Co-operation Administration. In addition to staff members from the Southwest Research Institute, the group, which is spending a month in Europe with headquarters at Bonn and Paris, includes research officers from the Armour Research Foundation of Chicago, the Battelle
Memorial Institute of Columbus, and the Stanford Research Institute of Palo Alto. The primary object is to determine whether a need exists for the establishment of applied research institutes to serve small and medium-sized manufacturers and processors in West Germany in the interest of national security and, if it does, how best to set up such laboratories. The West German Government itself asked for this survey to be made. The same group has already given assistance in establishing similar industrial research laboratories in Norway, and in the development of a programme leading to the inauguration of a scientific institute in Brazil. It is hoped to carry out similar surveys in other countries of Western Europe.

\section{Advisory Committee on Metals Economy}

The Minister of Supply, in conjunction with the Lord Privy Seal as Minister of Materials, has appointed an Advisory Committee on Metals Economy to help him to ensure the most economical use of metals in the engineering industry and in the defence programme. The terms of reference of the committee are: "To bring under review in consultation with the various Government and industrial authorities concerned ways of economizing in the use of scarce metals in the design, specification, and the manufacturing process of metal goods for both rearmament and civil purposes, and to advise the Government how it can best assist in promoting such developments".

The committee will be under the chairmanship of Mr. D. A. Oliver, director of research at the Birmingham Small Arms Co., Ltd. The other members are drawn from industry and Government departments. The industrial members are: Dr. G. L. Bailey, British Non-Ferrous Metals Research Association; Mr. H. A. R. Binney, British Standards Institution; Mr. H. H. Burton, English Steel Corporation, Ltd.; Mr. W. C. F. Hessenberg, British Iron and Steel Research Association; Mr. E. W. Grinham, Standard Motor Company, Ltd.; Dr. Ivor Jenkins, General Electric Co., Ltd. ; Dr. L. B. Pfeil, Mond Nickel Co., Ltd.; and Dr. C. J. Smithells, British Aluminium Co., Ltd. The secretary is Mr. K. M. McLeod, of the Engineering Industries Division of the Ministry of Supply.

\section{Student Health Services}

THE sixteenth issue of Communication, the organ of the International Association of University Professors and Lecturers, contains the Association's report upon the provision made in the universities of many countries for the health of their students. Some time ago a questionnaire was addressed to university authorities in all countries, thirty-six of which replied. In these thirty-six countries the great majority of universities accept the principle that they have some responsibility for the health of their students as well as for the way in which services should be organized and paid for. From the replies received it is clear that in the health examinations of the ordinary student at entrance to the university and on subsequent occasions very real importance is attached to the X-ray examination of the lungs. There is a general consensus of opinion that there should not be any exacting psychological examination of the ordinary student's mental health, although in some cases the help of a psychiatrist has been sought. The Association recommends that, in assessing the menta 